\title{
RISK ASSESSMENT AND MITIGATION STRATEGIES FOR AFRICAN MARKETS EXPANSION: THE CASE OF PHENIX CONSTRUCTION TECHNOLOGIES
}

\author{
Irina Onyusheva \\ Turan University, Almaty, Kazakhstan \\ Stamford International University, Bangkok, Thailand \\ Rajavadivel Santhanakrishnan \\ Stamford International University, Bangkok, Thailand
}

This paper is devoted to the issues of risk assessment and mitigation strategies. It also presents an academic adaptation of the comprehensive business expansion plan comprising of a business model, human resource planning, projected financial statements, marketing and sales plans developed and implemented by the Phenix Construction Technologies Company for African markets in the capacity of general and regional management experience of the company during 2014-2016.

Keywords: risk assessment, mitigation strategy, expansion, Africa.

\section{Company Profile}

Phenix Construction Technologies (PCT) is a steel building and steel manufacturing division of Ahmedabad-(India)-based M\&B Group of companies. It commenced the commercial production of pre-engineered buildings (PEB) in the year 2008 from its state-of-

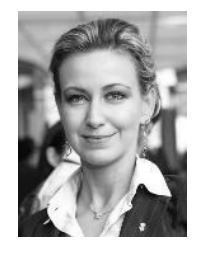

\section{Irina Onyusheva}

Dr., Prof., Turan University, Almaty, Kazakhstan; Stamford International University, Bangkok, Thailand

Interests - Economics, Strategic Management, Formation, ensuring and increasing economic competitiveness on both micro- and macro- levels; Human Capital development; HR Management; Knowledge Economy; Knowledge Management; Project Management; Management in Education

E-mail: dr.irina.onyusheva@gmail.com

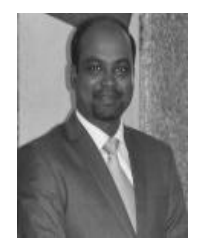

\section{Rajavadivel Santhanakrishnan}

Stamford International University, Bangkok, Thailand, International MBA Program Interests - International Business Management, Strategic Management, Global Markets

E-mail: 1709190004@students.stamford.edu 


\section{RISK ASSESSMENT AND MITIGATION}

art manufacturing facility at Sanand, Gujarat (India) with the annual capacity of 30,000MT. Soon after the recession, in 2012, PCT planned to enter international markets with a particular focus on Africa which offered huge potential as the concept of PEBs was still new for the most part of the continent. Subsequently, in 2014 after its success in Africa, PCT expanded its operations into the CIS and other SAARC countries using the same model.

\section{Industry Overview and Indian Market}

Though it is difficult to ascertain the year PEBs originated, the preponderance of steel building came to light in 1959 when Houston-based general contracting firm Kirby Building Systems first began marketing fabricated steel buildings with their standardized pre-designed and factory-built steel sections replacing traditional materials for columns and beams in industrial building constructions. Initially, pre-rolled standard structural steel sections such as 'I', ' $\mathrm{L}$ ', and ' $\mathrm{C}$ ' beams were used in the design. It all started as an onsite fabrication model with these standard sections being cut to design specifications and welded together at construction sites, thus making the final structure permanent and inflexible. Over the decades, technological meliorations in structural engineering and precocious manufacturing methods facilitated the adaptability of extreme sophistication and flexibility in creating innovative architectural designs. Moreover, lack of aesthetic compulsions in industrial building and the stress to boost productivity of the shop floor space paved way for wide span structures accommodating more equipment for manufacturing, inventory, packing, shipping, and other operations.

In 2000, acknowledging the huge potential of the Indian market, Kirby Building Systems Private Limited (KBSPL) set up its first manufacturing facility with the annual capacity of 40,000MT and soon became the first entrant at the Indian market monopolizing this sector for the next 8 years. This period can be called "the era of disruptive technological innovation in construction industry for India". The inceptive couple of years was a bumpy road for KBSPL wherein attributes such as lack of awareness about the market, dearth of specialized manpower both in design and installation, and highly unorganized supply chain all led to very slow growth. Over the years, rapid industrialization and the perception changes among industrial engineering consultants and architects pushed the growth of PEB against conventional brick-and-mortar constructions (Prabhakar, 2014). With high annual YoY growth rates between 20 and 25\%, Kirby constantly pumped massive investments into its Indian operations and in 2006 they set up their second manufacturing facility in Haridwar, adding 20,000MT to their annual production capacity.

Proliferation of 3PL warehousing and retail sectors increased the demand for steel buildings widening the demand-supply gap by 1.4 million tons per year thus opening the ground for other entrants into this sector (Sharma, 2014). Moreover, by 2012 India was set to be the fastest growing PEB market with $33 \%$ of conventional constructions shifting to steel buildings expecting the industry to grow further up to the level of US\$0.38 billion by 2014 . 
PCT's Indian operations. Many other sectors such as residential, educational institutions, hospitals, and exhibition centres adapted the PEB concept owing to its wide acceptance as an alternative construction technique with major advantages attributed to lower construction costs, the ability to meet strict project completion deadlines lowering the construction time by $30-40 \%$, the ability to provide efficacious insulation for tropical climatic conditions, and the relative ease of construction in hilly regions. Recognizing the potential in this industry, Ahmedabad-based M\&B Group, ventured into PEB manufacturing with technical collaboration joint venture with Varco Pruden Technologies, a US-based world's second largest steel building manufacturer, back in 2006 became the second entrant at the Indian market with Phenix Construction Technologies. The commercial production from PCT's state-of-art facility at Sanand, near Ahmedabad in Gujarat, commenced in 2008 when the world financial crisis just seeped in. Undeterred by the world economic crisis PCT continuously, but cautiously, invested in its manufacturing facility adding 20,000MT to its annual capacity to attain 55,000MT by 2012 and spread its sales network across the country taking advantage of low lending rates on capital funding backed by strong financial support from M\&B Group.

\section{PCT's need for international engagement}

As rightly described by Mr. Malav Patel, the Managing Director of PCT, PEB manufacturing is a derived industry dependent on the growth prospects, investment volumes, and expansion plans of other industries and sectors (Patel, 2014). The world economic crisis of 2008 had its impact on Indian businesses as the expansions within this country slowed down forcing many incumbents such as KBSPL and PCT compete against other large international and domestic late entrants, including Interarch Building Products Private Limited, Era Building Systems Limited, Tata Bluescope Steel, PEBS Pennar, Zamil Steel, Tiger Steel etc., thus converting KBSPL's once discovery of India as a blue ocean market into a zone of price wars within a span of 12 years. Rather than boosting value for customers at the price sensitive market, technological and operational efficiency innovations such as light gauge building for residential villas, incorporation of aesthetical features such as facias, utilization of high strength steel lowering input material costs, introduction of aesthetically pleasing coloured metal sheeting, adapting modern manufacturing techniques and machinery further escalated these price wars. When product and efficiency innovations reaches their saturation point, it would be prudent for far-sighted industries to lookout for new markets for expansion since competition becomes irrelevant due to the sheer size of the market rather than competing in red oceans. That is exactly the direction PCT shifted its strategic plans to sustain the business and therefore, it took a bold step of entering African markets in 2012. 


\section{RISK ASSESSMENT AND MITIGATION}

\section{Rationale behind entering African markets}

Though being the second entrant at Indian market, PCT tracked down couple of industry-experienced former employees of KBSPL turned entrepreneurs in Tanzania (Africa) and in Qatar (the Middle East) as potential marketing partners and forged strong alliances during the formative years of its existence.

Table 1. SWOT Analysis for African operations

(Compiled by the coauthors)

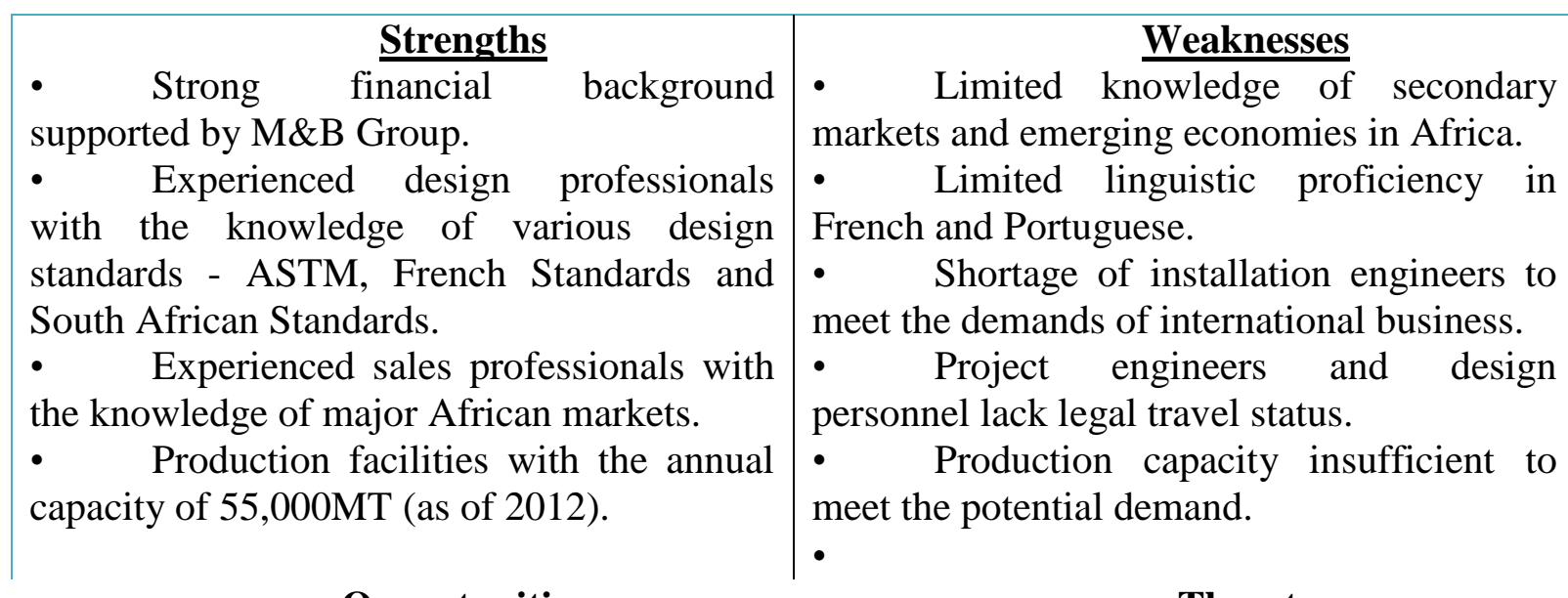

\section{Opportunities}

- $\quad$ Africa is a vast continent with 54 countries, 9 territories and 2 de-facto independent states.

- Market potential is at least US\$ 50 African nations.

billion with the YoY growth rate of $20 \%$.

- Africa overall is a mixed economy, thus, it has a huge potential for diversified industrial sectors.

- $\quad$ Nascent market as PEB not widely accepted, except in South Africa.

\section{Threats}

Competition from the side of the Middle East based PEB manufacturers

- Political instability in quite many

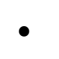


years back. Thus, in 2009 PCT became the first PEB manufacturer to ship out high-quality steel building structures from Indian ports to Africa. Going ahead Indian PEB manufacturers would not dare to enter the unexplored African markets till the end of 2014. With significant growth prospects forecasted for African construction sector, this industry's experts estimated that it would translate into an average YoY growth rate of $20 \%$ for PEBs and steel structures as the derivative industry.

\section{Proposed market entry strategy and long-term expansion plan}

Considering the endogenous and exogenous factors as suggested by Krzysztof Wach (2016), along with various additional factors of political, cultural and legal nature as well as all possible market entry modes available the members of PCT's exports team have formulated a comprehensive business strategy for expansion onto African markets which covers such issues as capital budgets, operational budgets, projected financials, comprehensive marketing and sales strategies etc. (Clarke, Robles, Akhter, \& Machado, 2008). The market entry strategy according to this business plan is outlined below.

Africa is a vast continent with 54 recognized sovereign states, 9 territories, and also 2 de-facto independent states. Covering such a vast territory with quite different governmental structures will be the single biggest challenge for the export team. Hence, the key African markets were identified as South Africa, Mozambique, Zambia, Tanzania, Kenya, Uganda, Ethiopia, and Nigeria. In these countries PCT will operate through a combination of entry modes, while in other countries PCT will adopt the project associate entry mode.

As the first step, PCT's internationalization process was set off by direct export mode through potential project associates in major African markets having all essential equipment and workforce to undertake installation works under PCT's supervision and financial support which includes the investment in materials on behalf of customers in certain cases.

A long-term plan is also in place for further expansion onto other African markets. The stages as described in detail below are suggested for stage-wise implementation in the next five years, stemming from the growth already achieved in the course of African operations.

Stage 1: Continental business headquarters should be established in South Africa by the second year of operations as a separate profit centre, with project associates at all other markets. This will be part of the strategy of direct export through company's subsidiary sales office.

Stage 2: Extending the direct export mode through regional sales offices in Kenya and Ghana should be set by the third year of operations while other markets will still be handled through project associates.

Stage 3: Establishing manufacturing facility through a joint venture in COEGA, Port Elizabeth as an African subsidiary for secondary materials such as girts, purlins, and metal sheeting constituting $30 \%$ of the steel-building components and exporting to other African markets. 


\section{RISK ASSESSMENT AND MITIGATION}

\section{Risk assessment and the adapted mitigation process.}

Entering African markets back in 2012 became PCT's first international venture, leaving aside the minor business it had in Tanzania between 2008 and 2012. Risk assessment and management are wholesome processes and should not be carried out in isolation. Keeping them separately may lead to inadvertent consequences up to complete failure of the internationalization process (Stowe \& Jeffery, 2008). Therefore, it has become critical for the PCT's export team to estimate the potential risks PCT will be exposed to and which could adversely affect the image of the company up to the level when these risks may potentially drive this quite profitable organization to bankruptcy. The authors, being aware of the vast geography and great deal of diversification within Africa, had to study each country separately and formulate country-specific business strategies and risk mitigation tactics. In general, the identified risks are outlined below:

1. Political landscapes of the eight African markets mentioned above are quite different, thus also "exerting different forces" on their local business environments. The political atmosphere across the continent ranges from stable democratic governments, long periods of dictatorships, bloody takeovers, emerging economies, those recovering from civil wars, and those still under transformational turmoil (Leading Edge Alliance, 2016).

2. Security of human capital and companies' assets are of primary concern for PCT. While Nigeria is reeling in civil war against terrorist organization, Boko Haram, severe crimes such as mugging, bag snatching, home invasions etc. are also quite common in many other parts of Africa too.

3. Bureaucratic process in African states is cumbersome making most documentation processes directly related to imports, exports, currency exchange, repatriation, taxation, land acquisitions, and business permits tedious.

4. Corruption and unethical business practices are rampant in most of African nations with only a few having scored 40 or below on the Corruption Perception Index compiled by the Transparency International.

5. Import tariffs vary significantly between the countries in question, and this fact has a huge impact on the project pricing rendering PCT's steel buildings uncompetitive or placing extreme pressure on the margins.

6. Climatic conditions have minimal effect as compared to many others factors that have been studied. The climate is primarily tropical, with dry summers in some areas. Tropical rain storms can turn destructive at times, thus adding extra pressure on the already unreliable national infrastructure.

7. Infrastructure is probably the most unreliable factor among all considered here and it remains to be the key risk when considering business operations in the identified African nations. Poor quality of roads combined with traffic congestions, vandalism, vehicles' theft, and armed burglary have inevitable impacts on all supply chain operations specifically in such landlocked countries as Uganda and Ethiopia (ContinuitySA, 2014). 
8. Power shortages and spikes are extremely common, and the situation in this regard has only worsened over the years due to constantly increasing demand (ContinuitySA, 2014).

9. Communications infrastructure across Africa, with South Africa and Rwanda as exceptions, is subject to inconsistent performance (ContinuitySA, 2014). Despite all the improvement and reforms' attempts over the years, lousy maintenance is still the root-cause of its repeatedly failures.

10. Recruitment and Succession Planning are hampered as skilled and experienced workforce remains to be the second biggest challenge in many countries all over the continent. Adding fuel to fire are the policies such as BBBEE that restricts expatriate employment (Obiyo, 2015). Visa and work permit regulations between the countries vary and is constantly under change affecting legitimation of expatriate workforce to be unfruitful at times. Moreover, security issues affect the return on investment as substantial costs are involved in expatriate employment (McNulty, Helen, \& Hutchings, 2009).

11. Cultural and language differences also have their huge impact on the way business is being conducted in Africa. Though English, French or Portuguese are used as official languages by the majority of African nations, the continent has the highest linguistic diversity with innumerable cultures influencing individual behaviours based on the tribe they belong to (Obiyo, 2015).

12. Epidemic diseases such as Ebola caused havoc in the recent past. Prevalence of other common diseases such as malaria and yellow fever make few African nations not an option for many expatriates.

13. Volatility of local currencies against the US dollar has adverse effects on the projects' costs and at times can lead to postponing or even shelving projects.

14. Cost of capital is much higher on African continent as the prime lending rates (even to the best among customers) is at least $40 \%$ higher than the interest rate in India, for example. Moreover, local banks traditionally perceive new companies as highly risky and hence boost their lending rates to mitigate the risks from potentially bad debts.

15. Resolving insolvency issues, such as accounting insolvency or cash-flow insolvency, could take years and still, as some experts believe, the local recovery rates are as low as $35 \%$.

Thorough analysis of each of the identified risks was conducted based on the data collected through the interviews with the consultants dealing with engineering design, business setup, taxation laws, labor laws, banking officials, customers, and also with the officials of various government departments in the African countries initially planned for market entry. Basing on the information collected, risk mitigation strategies are formulated and presented in Table 2 below. 


\section{RISK ASSESSMENT AND MITIGATION}

Table 2. Risks' Assessments and Risk Mitigation Strategies

\begin{tabular}{|c|c|c|}
\hline No. & Risk Identified & Risk Mitigation Strategies \\
\hline 1. & Political Instability & $\begin{array}{l}\text { At times of political unrests, local employees are supposed to } \\
\text { handle business operations, while expatriates need to be } \\
\text { evacuated. }\end{array}$ \\
\hline 2. & $\begin{array}{l}\text { Security threats to } \\
\text { personnel and to } \\
\text { property }\end{array}$ & $\begin{array}{l}\text { For office assets: Although this will incur additional costs, } \\
\text { employing a security agency and/or allocating funds for } \\
\text { general assets' insurance in the capital budget can be a good } \\
\text { option. } \\
\text { For staff: Staff evacuation plans should be devised and } \\
\text { appropriate service provider should be made available. All } \\
\text { necessary information should be shared with both the staff } \\
\text { and the service provider. }\end{array}$ \\
\hline 3. & $\begin{array}{l}\text { Long and tedious } \\
\text { bureaucratic process }\end{array}$ & $\begin{array}{l}\text { Employing fully knowledgeable external consultants that are } \\
\text { familiar with all current processes and procedures so that to } \\
\text { avoid delays due to inappropriate or insufficient } \\
\text { documentation. }\end{array}$ \\
\hline 4. & $\begin{array}{l}\text { Corruption \& } \\
\text { unethical business } \\
\text { practices. }\end{array}$ & $\begin{array}{l}\text { Strict internal policies should be formulated and staff should } \\
\text { be trained against unethical business practices. }\end{array}$ \\
\hline 5. & $\begin{array}{l}\text { Customs duty and } \\
\text { other import policies }\end{array}$ & $\begin{array}{l}\text { Local vendors should be identified for standard components } \\
\text { of the steel building thereby legally reducing the duty } \\
\text { assessable invoice value and thus lowering the import duties. }\end{array}$ \\
\hline 6. & Climate conditions & $\begin{array}{l}\text { Indian expatriates selected for the positions in Africa are } \\
\text { accustomed to tropical climate conditions which are very } \\
\text { much similar to those in India. However, they should be } \\
\text { provided first-hand information on climatic changes in } \\
\text { specific countries where PCT will be operating in. }\end{array}$ \\
\hline 7. & Poor infrastructure & $\begin{array}{l}\text { For the initial couple years, PCT should concentrate on doing } \\
\text { business generation in the countries with long coastal line } \\
\text { and well developed seaports. At this, the company should } \\
\text { choose the seaports that are close to large sites so that to } \\
\text { avoid road transportation as such. }\end{array}$ \\
\hline 8. & Power shortages & $\begin{array}{l}\text { Include capex budgets for diesel generators and recurring } \\
\text { expense budgets for fuel. }\end{array}$ \\
\hline 9. & $\begin{array}{l}\text { Communication } \\
\text { infrastructure }\end{array}$ & $\begin{array}{l}\text { Choose the best among the available service providers for the } \\
\text { mobile, Internet, and landline communications. }\end{array}$ \\
\hline 10. & $\begin{array}{l}\text { Labour policies } \\
\text { impacting company } \\
\text { HR policies. }\end{array}$ & $\begin{array}{l}\text { Ensure compliance with the local labour policies including } \\
\text { but not limited to BBBEE in staff recruitments and in other } \\
\text { HR-related activities. Hire suitable consultants for } \\
\text { knowledge sharing and guidance on these issues. }\end{array}$ \\
\hline 11. & $\begin{array}{l}\text { Cultural and } \\
\text { language differences }\end{array}$ & $\begin{array}{l}\text { Inculcate cultural tolerance among expatriate staff through } \\
\text { cultural training programmes and organize events to boost } \\
\text { socio-cultural relationship building with local employees }\end{array}$ \\
\hline
\end{tabular}




\begin{tabular}{|c|l|l|}
\hline 12. & $\begin{array}{l}\text { Personnel health } \\
\text { emergencies }\end{array}$ & $\begin{array}{l}\text { Expatriate staff should be required to undergo appropriate } \\
\text { vaccination process for yellow fever etc. Moreover, they } \\
\text { should be well briefed on all potential medical emergencies } \\
\text { and equipped with preventive medicines. Staff evacuation } \\
\text { plans should also include medical exigencies. }\end{array}$ \\
\hline 13. & $\begin{array}{l}\text { Local currencies' } \\
\text { volatility against the } \\
\text { US dollar }\end{array}$ & $\begin{array}{l}\text { Though not controllable, it would be wise to peg local } \\
\text { currencies with 7.5\% currency volatility factor against dollar } \\
\text { for all financial calculations. }\end{array}$ \\
\hline 14. & $\begin{array}{l}\text { Financing issues, } \\
\text { including those } \\
\text { related to high cost of } \\
\text { capital }\end{array}$ & $\begin{array}{l}\text { Avoid loans from the local markets as they are too costly. } \\
\text { Funding for capital budgets and initial operational expenses } \\
\text { should be processed in India. Once operating profits are } \\
\text { achieved, operational expenses should be catered from local } \\
\text { operations. }\end{array}$ \\
\hline 15. & $\begin{array}{l}\text { Insolvency } \\
\text { resolutions and debt } \\
\text { recovery }\end{array}$ & $\begin{array}{l}\text { Ensure strict debt control measures are in place. All accounts } \\
\text { receivables should be against letter of credit issued by } \\
\text { international bank or any other confirmed payment } \\
\text { instruments prior to shipping the materials. }\end{array}$ \\
\hline
\end{tabular}

\section{Conclusion}

Investing in African markets is a risky venture for PCT considering the perilous business environments that are often characterized by unpredictably precarious events. In the wake of the above analysis, PCT should test the waters by means of direct export through project associates before venturing into profit center operations.

\section{References:}

Clarke, R., Robles, F., Akhter, S., \& Machado, M. (2008). Determinants of International Equity Entry Mode: An Empirical Analysis. International Journal of Strategic Management, 8 (1).

Continuity S.A. (2014). Top 10 risks worth considering when expanding into Africa. (R. Warsop, Editor, \& ITWeb Limited) Retrieved Dec. 25, 2017, from itweb.co.za: https://www.itweb.co.za/content/XlwrKx73kXr7mg1o

Hill, C. W. (2013). The Strategy and Structure of International Business. In: C. W. Hill, B. Gordon, P. Ducham, \& J. Weimeister (Eds.), International Business: Competing in the Global Marketplace (9th ed., pp. 415-527). New York: The McGraw Hill Companies Inc.

Leading Edge Alliance. (2014). Business in Africa: The risks, rewards and challenges. St. Charles, IL: Leading Edge Alliance.

McNulty, Y., Helen, C. D., \& Hutchings, K. (2009). Do global firms measure expatriate return on investment? An empirical examination of measures, barriers and variables influencing global staffing practices. The International Journal of Human Resource Management, 20(6), 13091326.

Obiyo, C. (2015). 16 Challenges Of Doing Business In Africa... Oh Man! Retrieved Dec. 25, 2017, http://www.myafricanplan.com/2015/04/03/doing-business-in-africa/

Patel, M. (2014). Delivering complex projects is the name of the game. Big Interview, 20-22. SSMB.

Prabhakar, M. K. (2014). Indian PEB Industry: Economic and Environmental Sustainability Factors Ensure Continued Rapid Growth. Chennai: The Masterbuilder. 


\section{RISK ASSESSMENT AND MITIGATION}

Sharma, A. K. (2014). India: The Fastest Growing Market in PEB. (M. R, S. Gupta, P. C. Sharma, S. K. Khanna, J. Singh, P. P. Basistha, ... . V. Trehan, Editors) New Delhi, India: MGS Architecture.

Stowe, D. W., \& Jeffery, C. A. (2008). Risk management in isolation is risky. Financial Executive, pp. 26-29.

Wach, K. (2016). Chapter 7: Market entry modes for international businesses. In: K. Wach, \& E. Horská (Ed.), International Marketing: Within and Beyond Visegrad Borders (1st ed., pp. 135147). Lublin, Poland: Wydawnictwo Episeteme.

Paper submitted
Paper accepted for publishing
Paper published online

26 May 2018

06 August 2018

30 September 2018 